\title{
HEPATITIS E VIRUS IMMUNOGLOBULIN M (IgM) AND ASSOCIATED RISK FACTORS IN SOUTHWEST, NIGERIA
}

\author{
Adesina, O. A. ${ }^{1 *}$, Shodunke, O. C. ${ }^{1}$, Adedara, O. O. ${ }^{2}$, Oluyege, A. O. ${ }^{3}$ \\ ${ }^{1}$ Department of Microbiology, Obafemi Awolowo University, Ile-Ife, Nigeria. \\ ${ }^{2}$ State Primary Health Care Board, Ibadan, Oyo State. \\ ${ }^{3}$ Department of Microbiology, Ekiti State University, Ado-Ekiti, Nigeria. \\ E-mail addresses of authors-AOA: adesinafat@yahoo.co.uk or adesinaf@oauife.edu.ng; SOC: \\ oluwasefunmishodunke@gmail.com; AOO: tosindara2@gmail.com; OAO: aoluyege@gmail.com. \\ *Corresponding author. \\ (Received: $1^{\text {st }}$ July, 2020; Accepted: $8^{\text {th }}$ January, 2021)
}

ABSTRACT

\begin{abstract}
Hepatitis $\mathrm{E}$ is one of the most frequent causes of acute hepatitis worldwide, with an estimated 20 million infections and 70,000 deaths attributed to hepatitis E virus (HEV) genotypes 1 and 2 every year. This study was designed to determine the prevalence of HEV immunoglobulin M (IgM) in southwest (SW) Nigeria. Venous blood samples totalling 359 were collected from pregnant women on routine check, apparently healthy prospective blood donors and sick individuals presenting with fever and abdominal disturbance from health facilities in Ekiti, Lagos, Osun and Oyo states, of Nigeria. A structured questionnaire form was administered to gather socio-demographic data, health and travel history from each consenting participant. The screening for HEV IgM was done using HEV IgM ELISA kit. Statistical analyses, including descriptive analysis, correlations and binary logistic regression were carried out using SPSS version 21. In all, 131 samples $(36.5 \%)$ tested positive for HEV IgM. Osun state had the highest occurrence of $\operatorname{HEV~} \operatorname{IgM}(\mathrm{n}=49 ; 13.6 \%$, ) while Ekiti had the least ( $\mathrm{n}=$ 22; 6.1\%). Apparently healthy participants with detectable HEV IgM were 52 (14.5\%) while pregnant women were $51(14.2 \%)$. Risk factors implicated in this study were flooding and injection drug use. The overall HEV prevalence reported in this study was higher than previous reports in Nigeria. Higher HEV prevalence in this study could be due to a larger coverage area in the country as well as detection of ongoing infection. The detection of HEV IgM in pregnant women and apparently healthy prospective blood donors indicated ongoing infection with risk of spread to susceptibles since HEV is neither routinely screened for among pregnant women nor among prospective blood donors.
\end{abstract}

Keywords: Hepatitis E, IgM, Pregnancy, Apparently healthy, ELISA Depth, Geothermal Energy.

\section{INTRODUCTION}

Hepatitis $\mathrm{E}$ is the most frequent enterically transmitted, self-limiting, acute, viral hepatitis and currently considered an important public health problem worldwide (Pérez-Gracia et al., 2015; Khuroo and Khuroo, 2016). The disease is ecologically dependent, causes large-scale waterborne epidemics of viral hepatitis and is the most common cause of acute sporadic hepatitis and fulminant hepatic failure in resource-poor countries (Khuroo, 1991; Khuroo and Khuroo, 2015). The disease has unique and yet unexplained epidemiological characteristics, including repeated waves of large-scale epidemics, occurrence of disease in adult population and high incidence and severity of disease in pregnant women (Khuroo, 2011). The infection is prevalent in a wide range of animal species and human zoonotic hepatitis $\mathrm{E}$ is encountered in many developing and industrialized countries (Pavio et al., 2010; Thiry et al., 2015). Khuroo and Khuroo
(2016) reported that one-third of the world population has been exposed to hepatitis $E$ virus (HEV) as a result of varying unhygienic practices and, in some cases, relationship with the animal reservoirs. It has been estimated that two billion people, representing one third of the world's population, live in endemic areas for HEV and, therefore, are at a greater risk of infection than others in non-endemic areas (Holla et al., 2013).

In communities with poor sanitation conditions, especially in developing countries, transmission is primarily via the faecal-oral route through contaminated food or water, whereas in developed countries, sporadic and autochthonous cases of hepatitis $\mathrm{E}$ also occur in many parts of Europe, Asia, and North America (Dalton et al., 2008; Meng, 2011). Transmission can be water- or foodborne or zoonotic. Other routes of transmission said to account for a smaller number of clinical cases include the ingestion of undercooked meat 
or meat products derived from infected animals, transfusion of infected blood to uninfected patients and vertical transmission. The ingestion of raw or uncooked shellfish may be the source of sporadic cases in some endemic regions (WHO, 2010).

Hepatitis E is usually self-limiting but may develop into fulminant hepatitis with a case-fatality rate (CFR) between 1 and $2 \%$ in the general population (Skidmore, 2002), which can rise to over $40 \%$ in pregnant women, especially during the third trimester of pregnancy (Tsega et al., 1993). Maternal mortality due to HEV genotype 1 (HEV1) infection in pregnant women in developing countries has been found to be as high as $30 \%$, with most deaths occurring in the third trimester even though the reason for this is yet unclear (Lhomme et al., 2016). Apart from maternal death, stillbirths are common, as well as neonatal morbidity of those that survive after getting infected vertically (Khuroo et al., 1995; Khatun et al., 2012; Labrique et al., 2012). While clinical symptoms include fatigue, nausea, and jaundice which begin shortly after the increase of serum alanine aminotransferase (ALT) levels, clinical outcomes of hepatitis $\mathrm{E}$ has been known to vary from high endemic areas to low endemic regions. A majority of $\mathrm{HEV}$ infection cases either have no clinical consequences or minor illness with no liver damage (Aggarwal, 2013). HEV RNA disappears from the serum with recovery in about three weeks after the onset of symptoms, whereas the virus usually remains detectable longer in stools (Hoofnagle, 2012). Acute hepatitis $\mathrm{E}$ is usually self-limiting resolving in 6-7 weeks while the chronic condition ensues in both immunocompromised and immunocompetent patients most of them being asymptomatic and with a rapid progression to liver fibrosis especially among transplant recipients (González et al., 2011; de Niet et al., 2012; Kamar et al., 2012).

There is no known specific treatment capable of altering the course of acute hepatitis E because it is usually self-limiting. A recombinant subunit vaccine, Hecolin ${ }^{\circledR}$, was registered and licensed in China in December 2011 for use in people aged $>16$ years. The major way to avoid contracting hepatitis $\mathrm{E}$ is to avoid drinking unsanitary water and to maintain a good personal sanitation. Also, travelers to $\mathrm{HEV}$-endemic regions such as Asia, Africa, the Middle East, and Central America should avoid water of unknown purity, food from street vendors, raw or undercooked seafood, meat or pork products, and raw vegetables. Travelers to Europe, on the other hand, should also avoid uncooked and undercooked pork/boar sausage or other wild animal meats that have not been properly cooked. This study was designed to determine the prevalence of HEV IgM antibodies and associated risk factors among different categories of study participants in Ekiti, Lagos, Osun and Oyo states of Nigeria.

\section{MATERIALS AND METHODS}

\section{Study Locations}

The study locations included, at least one health facility of either primary or secondary level in each of the four states involved in this study, namely: Ekiti, Lagos, Osun and Oyo states in southwest Nigeria. These southwest states are homes to the Yoruba race although people of other tribes also live with them. The states have many tertiary institutions and are densely populated, though with a high literacy level. The region belongs to the tropical rainforest zone, rich in plant populations with diverse kinds of forest animals.

\section{Enrolment of Study Participants}

Participants for the study included randomly selected apparently healthy prospective blood donors, pregnant women on routine medical check and sick individuals (presenting with symptoms including fatigue, fever, abdominal disturbance, nausea, and vomiting) all with no known ongoing treatment for hepatitis. Ethical approval (SERC-2017-001 OAUS) and permission to conduct the research were obtained from the health institutions as well as written and/or verbal consents of the participants as applicable.

\section{Sample Collection}

Sample collection was done between October 2016 and February 2018. Three (3) milliliters of venous blood was collected from each consenting subject into well-labelled sterile plain bottles with the help of the medical personnel in the various health facilities. The blood samples were separated into serum and packed cells after spinning at 3,000 
revolutions per minute (RPM) for 10 minutes. The serum samples were then collected and stored in appropriately labelled cryovials, transported to the laboratory on ice pack for storage at $-20{ }^{\circ} \mathrm{C}$ until analysed. Sample size was determined for crosssectional surveys/studies using Noordhuizen et al., (2001) formular:

$n=\frac{z^{2} p q}{d^{2}}$

where

$\mathrm{n}=$ desired sample size

$z=$ the standard normal deviate at $95 \%$

confidence interval $(=1.96)$.

$\mathrm{p}=$ the proportion in the target population

estimated to have had hepatitis (1.3).

$\mathrm{q}=1-\mathrm{p}$,

$\mathrm{d}=$ level of precision (set at 0.05 ).

A total of 359 venous blood samples were used.

\section{Data Collection}

A structured questionnaire was administered to each subject to gather information, among others, on socio-demography, knowledge about hepatitis, supposed risk factors, symptoms, travel and medical histories.

\section{Laboratory Procedure}

HEV IgM Serology

The serum samples were analysed to screen for hepatitis E virus immunoglobulin (Ig) M.

The serum samples screened were allowed to attain room temperature. The wells of the ELISA plate were labelled to correspond with blank, cutoff, positive and negative controls according to the kit manufacturer's instructions. The ELISA kit (HEV-IgM kit, Dia.Pro Diagnostic Bioprobes, Italy) was also allowed to attain room temperature before use. According to manufacturers instructions, each sample was separately diluted
1:101 by adding $10 \mu \mathrm{l}$ of the sample to $1000 \mu \mathrm{l}$ of the sample diluents (provided in the ELISA kit). For the assay, $100 \mu \mathrm{l}$ of each diluted sample was used following manufacturer's instructions. Summarily, the procedure included addition of the diluted samples to neutralizing reagent in the prelabelled microwells of the micro-titre plate followed by first incubation, then first washing after which enzyme conjugate was added and then, second incubation, followed by second washing, then addition of chromogen/substrate and a final incubation in the dark after which the reaction was stopped with a stop solution. On addition of the stop solution, the positive samples which were previously blue, turned yellow while the negative ones remained colourless.

\section{Data Analysis}

Data obtained from the administered questionnaires and the laboratory analysis were analysed using SPSS version 21. Descriptive, correlation and some regression analyses of the data were carried out to be able to draw some inferences and likely conclusions from the study.

\section{RESULTS}

The HEV IgM screening showed that 131 (36.5\%) of the 359 study participants had detectable HEV IgM antibodies while $228(63.5 \%)$ had no detectable HEV IgM. The state-by-state analysis of the HEV IgM distribution showed that Osun had the highest occurrence rate of $13.6 \%$ ( $n=$ 49/96) out of all the samples screened while Ekiti had the least with $6.1 \%(n=22 / 92)$ occurrence rate (Figure 1). There is a statistically significant relationship between states of sample collection and HEV IgM positivity with a $p$ value of 0.001 at 95\% Confidence Interval (CI) using binary logistic regression. 


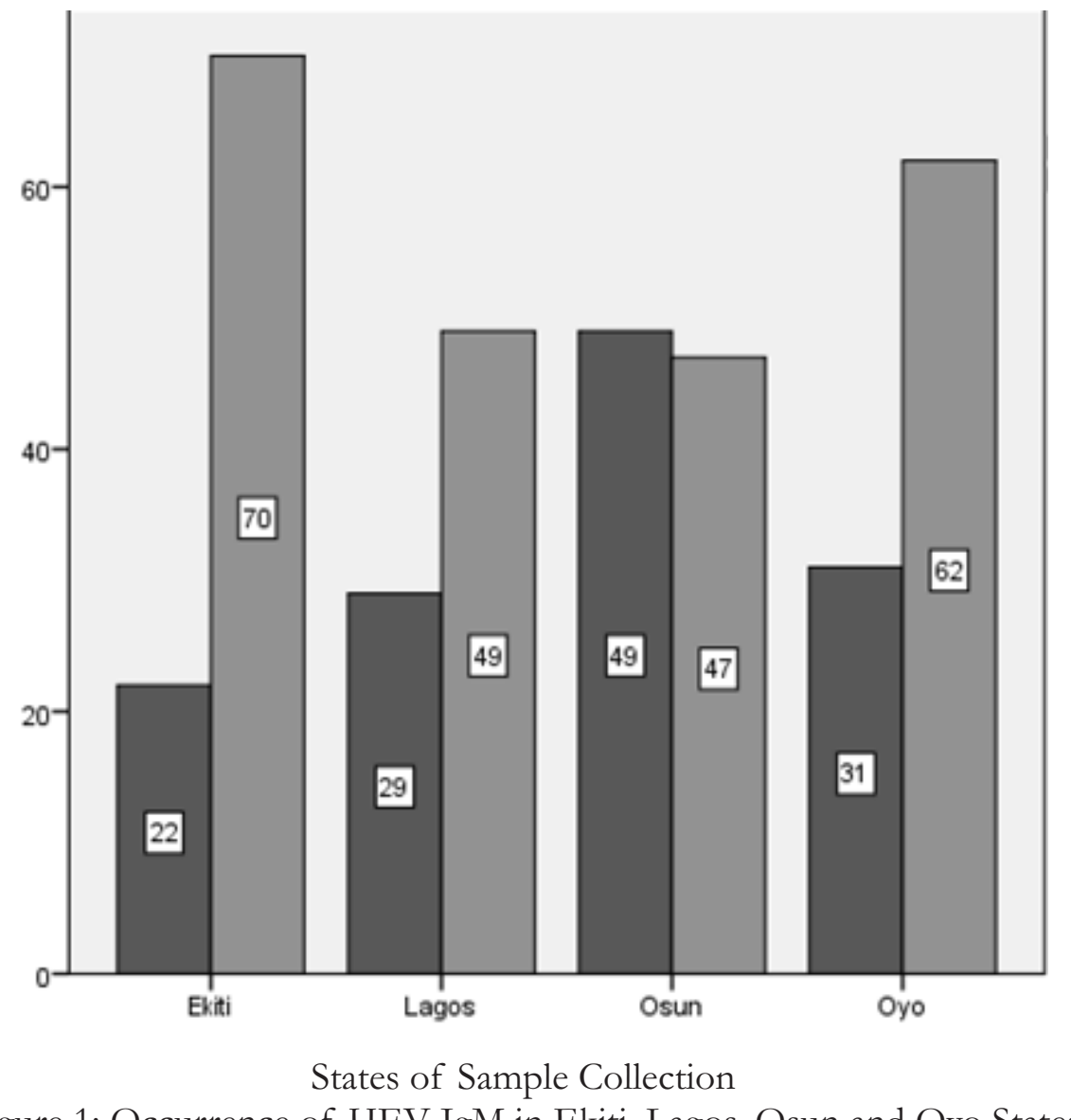

Figure 1: Occurrence of HEV IgM in Ekiti, Lagos, Osun and Oyo States

HEV IgM Positive

A general comparison of the HEV IgM positivity among the study participants showed that $14.5 \%$ $(n=52 / 165)$ and $7.8 \%(n=28$ out of 79$)$ cases were observed in apparently healthy prospective blood donors and sick individuals, respectively. Further details are shown in figure 2 .
HEV IgM Negative

Out of the 165 apparently healthy individuals screened from the four states, $13.3 \%(n=22), 9.7 \%$ $(n=16)$ and $0.6 \%(n=1)$ were respectively from Osun, Ekiti and Lagos states. Details of the distribution of the HEV IgM among other categories in the states are shown in table 1. 


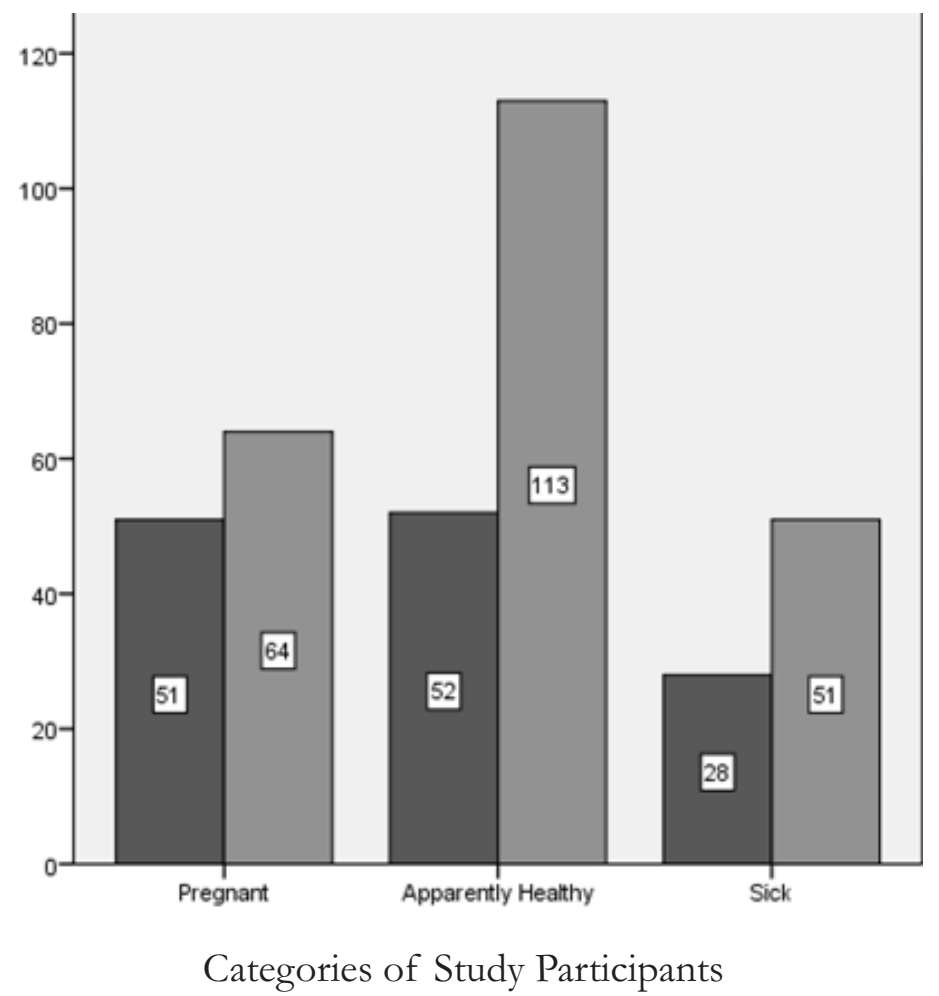

Figure 2: Distribution of Anti-HEV IgM Antibodies Among the Pregnant Women, Apparently Healthy and Sick Individuals in Ekiti, Lagos, Osun and Oyo States, Nigeria

HEV IgM Positive HEV IgM Negative

Table 1: Distribution of HEV IgM Positive Individuals Among the Various Categories of Participants Studied in the Four States

\begin{tabular}{|c|c|c|c|c|c|c|c|}
\hline \multirow{2}{*}{\multicolumn{3}{|c|}{ Categories of Participants }} & \multicolumn{4}{|c|}{ States of Sample Collection } & \multirow[b]{2}{*}{ Tota } \\
\hline & & & Ekiti & Lagos & Osun & Oyo & \\
\hline \multirow[t]{3}{*}{ Pregnant } & HEV IgM & Positive & 5 & 27 & 9 & 10 & 51 \\
\hline & Result & Negative & 5 & 45 & 8 & 6 & 64 \\
\hline & Total & & 10 & 72 & 17 & 16 & 115 \\
\hline Apparently & HEV IgM & Positive & 16 & 1 & 22 & 13 & 52 \\
\hline \multirow[t]{2}{*}{ Healthy } & Result & Negative & 57 & 1 & 20 & 35 & 113 \\
\hline & Total & & 73 & 2 & 42 & 48 & 165 \\
\hline \multirow[t]{3}{*}{ Sick } & HEV IgM & Positive & 1 & 1 & 18 & 8 & 28 \\
\hline & Result & Negative & 8 & 3 & 19 & 21 & 51 \\
\hline & Total & & 9 & 4 & 37 & 29 & 79 \\
\hline \multirow[t]{3}{*}{ Total } & HEV IgM & Positive & 22 & 29 & 49 & 31 & 131 \\
\hline & Result & Negative & 70 & 49 & 47 & 62 & 228 \\
\hline & Total & & 92 & 78 & 96 & 93 & 359 \\
\hline
\end{tabular}

The incidence of HEV IgM according to gender was observed to be $28.1 \%(n=101 / 252)$ females and $8.4 \% \quad(\mathrm{n}=30 / 107)$ males. A general consideration of the distribution of $\mathrm{HEV}$ IgM based on gender in this study showed that $40.1 \%$ $(n=101 / 252)$ of the females and $28 \%(n=30 / 107)$ of the males were HEV IgM positive. Gender as a factor was observed to have a significant Pearson
Chi-Square p value of 0.03 . Osun state recorded the highest HEV IgM occurrence in both genders with $15 \%(n=16 / 107)$ of the males and $13.1 \%$ $(n=33 / 252)$ of the females screened. There were generally fewer HEV IgM positive males than females observed across the four studied states as shown in figure 3 . 


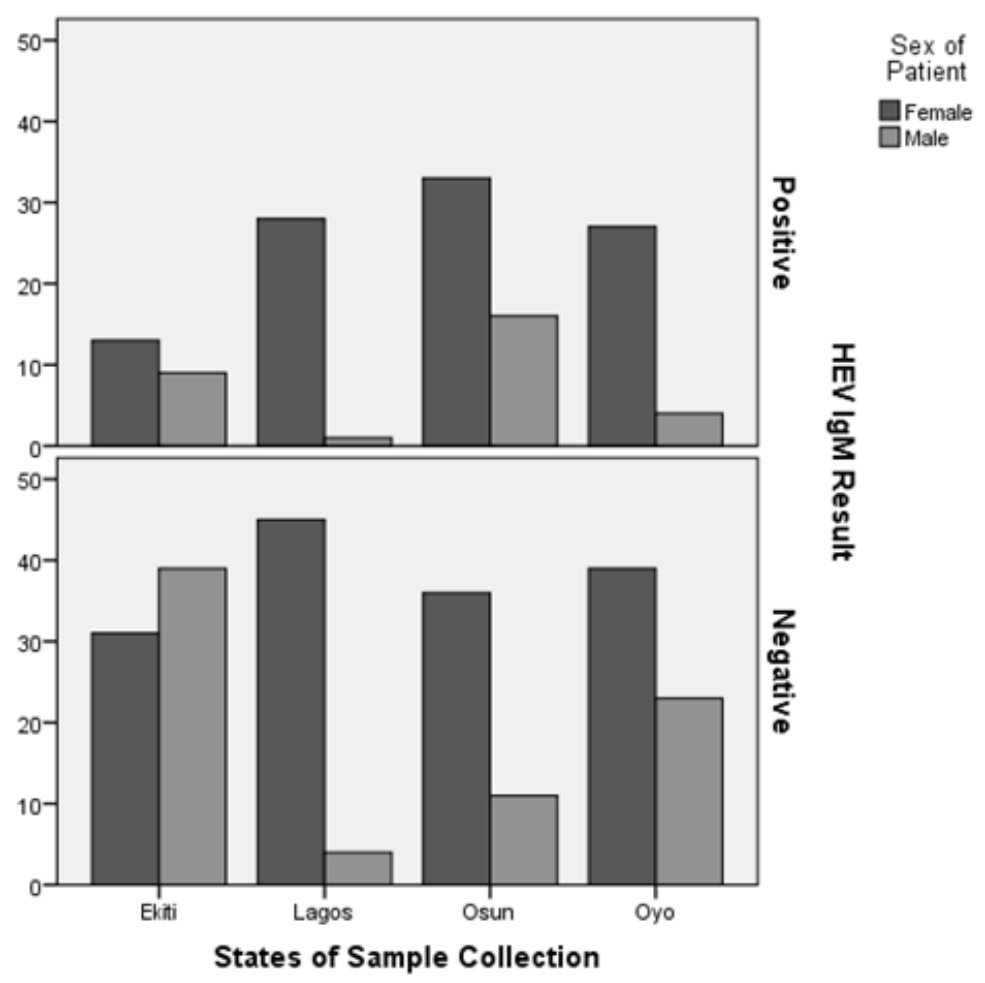

Figure 3: General Distribution of HEV IgM with Gender in Ekiti, Lagos, Osun, and Oyo States

\section{HEV IgM Positive}

This study showed that the most affected age group in the occurrence of HEV IgM are the $41-$ 50 years $(n=19 / 35)$ making $54.3 \%$ with 12 $(63.2 \%)$ out of the 19 from Osun state while it is followed by 31 - 40 years ( $n=44 / 106)$ making $41.5 \%$ with $17(38.6 \%)$ out of the 44 coming from

\section{HEV IgM Negative}

Osun state thus having the highest in both age groups. The occurrence of HEV IgM among the age groups in the states are as shown in table 2. Injecting drug use and flooding were observed to have significant association with HEV positivity. Further details are as shown in table 3. 
Table 2: Distribution of HEV IgM According to Age Range of Study Participants

\begin{tabular}{|c|c|c|c|c|c|c|c|}
\hline \multirow{2}{*}{\multicolumn{3}{|c|}{ Age Range }} & \multicolumn{4}{|c|}{ States of Sample Collection } & \multirow{3}{*}{$\begin{array}{c}\text { Total } \\
0\end{array}$} \\
\hline & & & \multirow{2}{*}{$\begin{array}{c}\text { Ekiti } \\
0\end{array}$} & \multirow{2}{*}{$\begin{array}{c}\text { Lagos } \\
0\end{array}$} & \multirow{2}{*}{$\begin{array}{c}\text { Osun } \\
0\end{array}$} & \multirow{2}{*}{$\begin{array}{c}\text { Oyo } \\
0\end{array}$} & \\
\hline $0-10$ & HEV IgM & Positive & & & & & \\
\hline & Result & Negative & 0 & 1 & 2 & 0 & 3 \\
\hline & Total & & 0 & 1 & 2 & 0 & 3 \\
\hline \multirow[t]{3}{*}{$11-20$} & HEV IgM & Positive & 1 & 1 & 2 & 5 & 9 \\
\hline & Result & Negative & 3 & 4 & 3 & 18 & 28 \\
\hline & Total & & 4 & 5 & 5 & 23 & 37 \\
\hline \multirow[t]{3}{*}{$21-30$} & HEV IgM & Positive & 13 & 12 & 14 & 11 & 50 \\
\hline & Result & Negative & 49 & 20 & 20 & 9 & 98 \\
\hline & Total & & 62 & 32 & 34 & 20 & 148 \\
\hline \multirow[t]{3}{*}{$31-40$} & HEV IgM & Positive & 5 & 16 & 17 & 6 & 44 \\
\hline & Result & Negative & 11 & 23 & 12 & 16 & 62 \\
\hline & Total & & 16 & 39 & 29 & 22 & 106 \\
\hline \multirow[t]{3}{*}{$41-50$} & HEV IgM & Positive & 3 & 0 & 12 & 4 & 19 \\
\hline & Result & Negative & 4 & 1 & 3 & 8 & 16 \\
\hline & Total & & 7 & 1 & 15 & 12 & 35 \\
\hline \multirow[t]{3}{*}{$51-60$} & HEV IgM & Positive & 0 & 0 & 2 & 1 & 3 \\
\hline & Result & Negative & 2 & 0 & 2 & 8 & 12 \\
\hline & Total & & 2 & 0 & 4 & 9 & 15 \\
\hline \multirow[t]{3}{*}{$>60$} & HEV IgM & Positive & 0 & 0 & 2 & 4 & 6 \\
\hline & Result & Negative & 1 & 0 & 5 & 3 & 9 \\
\hline & Total & & 1 & 0 & 7 & 7 & 15 \\
\hline \multirow[t]{3}{*}{ Total } & HEV IgM & Positive & 22 & 29 & 49 & 31 & 131 \\
\hline & Result & Negative & 70 & 49 & 47 & 62 & 228 \\
\hline & Total & & 92 & 78 & 96 & 93 & 359 \\
\hline
\end{tabular}


Table 3: Some of the Risk Factors Associated with HEV IgM Positivity in Southwest, Nigeria

RISK FACTORS

HEV IGM

P VALUE

\begin{tabular}{|c|c|c|c|c|}
\hline \multirow{3}{*}{ Had blood transfusion* } & & Positive (\%) & Negative $(\%)$ & \\
\hline & No & $122(37.2)$ & $206(62.8)$ & \multirow{2}{*}{0.423} \\
\hline & Yes & $5(31.3)$ & $11(68.7)$ & \\
\hline \multirow[t]{2}{*}{ Organ transplant* } & No & $126(37.4)$ & $211(62.6)$ & \multirow{2}{*}{0.200} \\
\hline & Yes & $1(14.3)$ & $6(85.7)$ & \\
\hline \multirow{2}{*}{$\begin{array}{l}\text { Medical history of } \\
\text { hepatitis* }\end{array}$} & No & $123(36.6)$ & $213(63.4)$ & \multirow{2}{*}{0.233} \\
\hline & Yes & $4(57.1)$ & $3(42.9)$ & \\
\hline \multirow{2}{*}{$\begin{array}{l}\text { Family diagnosed of } \\
\text { hepatitis* }\end{array}$} & No & $116(36.5)$ & $202(63.5)$ & \multirow{3}{*}{0.175} \\
\hline & Yes & $12(48)$ & $13(52)$ & \\
\hline \multirow[t]{2}{*}{ Injecting drug use* } & No & $122(36)$ & $217(64)$ & \\
\hline & Yes & $6(85.7)$ & $1(14.3)$ & $0.012^{* *}$ \\
\hline \multirow[t]{2}{*}{ Eat game meat* } & No & $101(36.2)$ & $178(63.8)$ & \multirow{2}{*}{0.266} \\
\hline & Yes & $28(41.2)$ & $40(58.8)$ & \\
\hline \multirow[t]{2}{*}{ Had flooding* } & No & $91(38.4)$ & $146(61.6)$ & \multirow[b]{2}{*}{$0.023^{* *}$} \\
\hline & Yes & $14(23.7)$ & $45(76.3)$ & \\
\hline \multirow{6}{*}{$\begin{array}{l}\text { Drinking water } \\
\text { source* }\end{array}$} & Tap & 77 (33) & $156(67)$ & \multirow{4}{*}{0.335} \\
\hline & Stream & $9(47.4)$ & $10(52.6)$ & \\
\hline & Bore hole & $6(40)$ & $9(60)$ & \\
\hline & Well & $22(42.3)$ & $30(57.7)$ & \\
\hline & Sachet & $8(53.3)$ & $7(46.7)$ & \multirow{5}{*}{0.123} \\
\hline & Others & $6(50)$ & $6(50)$ & \\
\hline \multirow[t]{3}{*}{ Eating out* } & Always & $36(40.4)$ & $53(59.6)$ & \\
\hline & Sometimes & $65(32.8)$ & $133(67.2)$ & \\
\hline & NEVER & 27 & 31 & \\
\hline
\end{tabular}

\section{DISCUSSION}

We report a high HEV prevalence of $36.5 \%$ in south west Nigeria. To the best of our knowledge, this study is the first reported HEV single study covering four (4) states in Nigeria, hence the possible reason for the high prevalence, since HEV occurrence was found to be associated with location in the study. Some of the previously reported hepatitis $\mathrm{E}$ prevalence in Nigeria included $0.4 \%$ in pregnant women among Anambra and Oyo community dwellers in two different geographical regions of Nigeria, although there was $0 \%$ prevalence among other participants in the same study (Ifeorah et al., 2017). In addition, $0.9 \%$ was reported among different populations including apparently healthy 
individuals in Plateau state (Junaid et al., 2014) and 9\% was reported by Fowotade $e$ t al. (2018) among restaurant food handlers in Ibadan, Oyo State.

In a pilot study on the seroprevalence of antiHEV among blood donors in Lagos, Nigeria, John-Olabode et al. (2017) reported an overall HEV seroprevalence of $6.6 \%$, HEV $\mathrm{IgG}$ prevalence of $5.3 \%$ and $\mathrm{HEV}$ IgM of $1.3 \%$ among 151 blood donors. Also, Oladipo et al. (2017) reported HEV antibody prevalence of $2.7 \%(5 / 186)$ among apparently healthy individuals in Ogbomoso, Oyo state. In a much earlier study, Adesina et al. (2009) reported HEV IgM prevalence of $13.4 \%(\mathrm{~N}=186)$ among sick and healthy individuals in Ekiti state. This study is thus positing a possible increase in hepatitis E prevalence in SW Nigeria in recent times, however, a single study may not be sufficient to conclude on this, hence the need for further studies spanning some years. From this study, state based HEV occurence rate showed the highest prevalence of $13.6 \%$ in Osun state compared to a recent study which reported a prevalence of $3.8 \%$ (Osundare et al., 2020). On the other hand, Ekiti State showed the lowest occurrence of $6.13 \%$ compared to $13.4 \%(25 / 186)$ reported by Adesina et al. (2009).

Although, paucity of data exist on the occurrence and the distribution of HEV antibodies in $\mathrm{Oyo}$ state, it can be observed that there is an increase in the prevalence in relation to some of the limited reports available and the observed occurence of $8.64 \%$ in this study. Oluremi et al. (2020) reported an occurrence of $0.2 \%(2 / 904)$ in a recent report. Increase in HEV IgM prevalence as observed in the states with previous HEV published data shows the need for putting a robust HEV surveillance system in place, to prevent hepatitis $\mathrm{E}$ outbreak in Nigeria. The increase could have been probably due to limited hepatitis E awareness, diagnosis and prevention compared to hepatitis B and C.

Fewer $(7.8 \%)$ sick individuals were observed to have hepatitis E compared to apparently healthy $(14.5 \%)$ and pregnant women $(14.2 \%)$ in this study. This is different from what Adesina et al. (2009) reported in Ekiti state where 20 of the 25 HEV IgM positive individuals were sick of fever and abdominal disturbance while the remaining 5 were apparently healthy individuals on routine medical checkup. The higher HEV prevalence reported among the apparently healthy and pregnant women than the sick individuals is an issue for consideration in the epidemiology of hepatitis $\mathrm{E}$ in Nigeria. It has been said that hepatitis $\mathrm{E}$ is often asymptomatic and self limiting but the reason for this has not been fully deciphered. Regular molecular studies of HEV is important so as to understand the likelihood of and how to handle the emergence of resistance HEV strains due to natural pressure on the virus (being an RNA virus). This will hopefully make clinical diagnosis less difficult and enhance vaccine development/ effectiveness.

A higher fatality of $42.1 \%$ was reported in Ethiopia (Tsega et al., 1993) while it was $12.5 \%$ during an outbreak in Kenya (Ahmed et al., 2013) and $10 \%$ or more in south Asia (Labrique et al., 2012; Gurley et al., 2012).

Flooding and injecting drug use showed significant association with $\mathrm{HEV}$ positivity and hence could be referred to as likely risk factors for the spread of HEV in this study. Injecting drug use is an uncommon route of HEV transmission in developing countries like Nigeria as this group of people have not been studied for HEV transmission. The significant relationship between injecting drug use and HEV $\operatorname{IgM}$ obtained in this study is suggesting that it is also a potential route of transmission of hepatitis $E$ in developing countries because it was only reported among injecting drug users of ages $18-40$ years in California, USA (Mahajan et al., 2013).

Different types of occupation were considered to see their effects on the transmission of HEV. Not much has been known about the role of occupation in HEV transmission but a significant association between occupational exposure to swine and HEV IgG seroprevalence was reported in some developed countries (De Schryver et al., 2015). Due to the zoonotic form of hepatitis E, most occupations that involve animals that have been implicated in HEV transmission are potential risk factors if necessary precautionary measures are not taken. However, those that are self employed, students, traders and civil servants 
were found to have HEV IgM prevalence ranging from $6.4 \%$ to $8.1 \%$ in this study. Furthermore, Junaid et al. (2014) reported rural dwelling, attending to animals, blood transfusion and waste disposal as associated risk factors in the seroprevalence of HEV IgM in Plateau state, Nigeria.

In conclusion, our study being the first single study covering four states in south western Nigeria shows that HEV occurrence was associated with location, hence a high HEV IgM prevalence in the study population. It also implicated injecting drug use as a possible major means of HEV transmission in Nigeria, which was formerly adduced to the developed countries, suggesting the need to encourage more epidemiological HEV studies.

\section{ACKNOWLEDGEMENTS}

The authors appreciate all the participants in this study for their consent. We also thank the members of staff of the various laboratories and health facilities involved in this study for their professional support during sample collection.

\section{REFERENCES}

Adesina, O.A, Japhet, M. O., Donbraye, E, Kumapayi, T. E and Kudoro, A (2009). Anti-hepatitis $\mathrm{E}$ virus antibodies in sick and healthy individuals in Ekiti state, Nigeria. African Journal of Microbiological Research, 3(9): 533-536.

Aggarwal, R. (2013). Hepatitis E: epidemiology and natural history. Journal of Clinical and Experimental Hepatology, 3(2):125-133

Ahmed, J.A., Moturi, E., Spiegel, P., Schilperoord, M., Burton, W., Kassim, N.H., Mohamed, A., Ochieng, M., Nderitu, L., NavarroColorado, C., Burke, H., Cookson, S., Handzel, T., Waiboci, L.W., Montgomery, J.M., Teshale, E., Marano, N. (2013). Hepatitis E outbreak, Dadaab refugee camp, Kenya, 2012. Emerging Infectious Disease, 19:1010-1012

Dalton, H., Bendall, R., Ijaz, S. and Banks, M. (2008). Hepatitis E: an emerging infection in developed countries. Lancet Infectious Diseases, 8: 698-709.

de Niet, A., Zaaijer, H. L., ten Berge, I., Weegink, C. J., Reesink, H. W., and Beuers, U. (2012).
Chronic hepatitis E after solid organ transplantation. The Netherlands Journal of Medicine, 70(6): 261-266.

De Schryver, A., De Schrijver, K., François, G., Hambach, R., van Sprundel, M., Tabibi, R., and Colosio, C. (2015). Hepatitis E virus infection: an emerging occupational risk? Occupational Medicine, 65(8): 667-672.

Fowotade A., Akande, O., Gbaja, A. T., Ogunleye, V. O., Ajayi, A., Kehinde, A. O. (2018). Seroprevalence of hepatitis $\mathrm{E}$ among restaurant food handlers in Ibadan, Nigeria. Tanzania Journal of Health Research, 20(3):1- 7.

González Tallón, A. I., Moreira Vicente, V., Mateos Lindemann, M. L., and Achécar Justo, L. M. (2011). Hepatitis crónica E en paciente inmunocompetente [Chronic hepatitis $\mathrm{E}$ in an immunocompetent patient]. Gastroenterologia y Hepatologia, 34(6):398-400.

Gurley, E. S., Halder, A. K., Streatfield, P. K., Sazzad, H. M., Huda, T. M., Hossain, M. J., Luby, S. P. (2012). Estimating the burden of maternal and neonatal deaths associated with jaundice in Bangladesh: possible role of hepatitis $\mathrm{E}$ infection. American Journal of Public Health, 102:2248-2254

Holla, R. P., Ahmad, I., Ahmad, Z. and Jameel, S. (2013). Molecular virology of hepatitis E virus. Seminars in Liver Disease, 33(1):3-14.

Hoofnagle, J. H., Nelson, K. E., Purcell, R. H. (2012). Hepatitis E current concepts. New England Journal of Medicine, 367:1237-44.

Ifeorah, I. M., Faleye, T., Bakarey, A. S., Adewumi, M. O., Akere, A., Omoruyi, E. C., Ogunwale, A. O., and Adeniji, J. A. (2017). Acute hepatitis $\mathrm{E}$ virus infection in two geographical regions of Nigeria. Journal of Pathogens, 2017,4067108 . https:/ / doi.org/10.1155/2017/4067108

John-Olabode, S. O., Ajie, O., Osunkalu, V., Akinbami, A. and Aile, K. (2017). Seroprevalence of anti- HEV among blood donors in Lagos, Nigeria- A pilot study Journal of Microbiology Research, 3(4): 203-207

Junaid, S. A., Agina, S. E. and Abubakar, K. A. (2014). Epidemiology and associated risk factors of hepatitis e virus infection in 
plateau state, Nigeria. Virology: Research and Treatment, 5: 15-26.

Kamar, N., Legrand-Abravanel, F., Izopet, J., Rostaing, L. (2012). Hepatitis E virus: what transplant physicians should know. American Journal of Transplant, 12: 2281-7.

Khatun, F., Rasheed, S., Moran, A. C., Alam, A. M., Shomik, M. S., Sultana, M., Choudhury, N., Iqbal, M., and Bhuiya, A. (2012). Causes of neonatal and maternal deaths in Dhaka slums: implications for service delivery. BMC Public Health, 12: 84. https:// doi.org/10.1186/1471-2458-1284.

Khuroo, M. S. (1991). Hepatitis E: the enterically transmitted non-a, non-b hepatitis. Indian Journal of Gastroenterology, 10: 96-100.

Khuroo, M. S. (2011). Discovery of hepatitis E: The epidemic non-a, non-b hepatitis 30 years down the memory lane. Virus Research, 161:3-14

Khuroo, M. S., Kamili, S., and Jameel, S. (1995). Vertical transmission of hepatitis $\mathrm{E}$ virus. Lancet, 345: 1025-1026. http:// dx.doi.org/10.1016/S0140-6736(95) 90761-0.

Khuroo, M.S. and Khuroo, M.S. (2015). Sanitation and sewage disposal in India. JKPractitioner, 20: 43-46.

Khuroo, M. S. and Khuroo, M. S. (2016). Hepatitis $\mathrm{E}$ : an emerging global disease-from discovery towards control and cure. Journal of ViralHepatology, 23: 68-79.

Labrique, A. B., Sikder S. S., Krain, L. J., West, K. P. Jr, Christian, P., Rashid, M., and Nelson, K. E. (2012). Hepatitis E, a vaccinepreventable cause of maternal deaths. Emerging Infectious Disease, 18:1401-1404.

Lhomme, S., Marion, O., Abravanel, F., ChapuyRegaud, S., Kamar, N. and Izopet, J. (2016). Hepatitis E pathogenesis. Viruses, 8(8): 212.

Mahajan, R., Collier, M. G., Kamili, S., Drobeniuc, J., Cuevas-Mota, J., Garfein, R. S. and Teshale, E. (2013). Hepatitis E virus among persons who inject drugs, San Diego, California, USA, 2009-2010. Emerging Infectious Diseases, 19(10): $1664-1666$.

Meng, X. J. (2011). From barnyard to food table: The omnipresence of hepatitis $\mathrm{E}$ virus and risk for zoonotic infection and food safety. Virus Research, 161:23-30.

Noordhuizen, J. P. T. M., Frankena, K., Thrusfield, M. V., and Graat, E. A. M. (2001). Application of quantitative methods in veterinary epidemiology, second, revised reprint. Wageningen Pers.

Oladipo, E. K., Awoyelu, E. H. and Oloke, J. K. (2017). Human hepatitis E virus among apparently healthy individuals in Ogbomoso, south western Nigeria. Journal of Human Virology and Retrovirology, 5(1): 00137.

Oluremi, A. S., Opaleye, O. O., Ogbolu, D. O., Alli, O., Adeola, O., Alaka, O., Ogunleke, O. A., Ojo, A., Bello, M. D., Enitan, S. S., Adediji, I. O., Adelakun, A. A., and Suleiman, I. E. (2020). High viral hepatitis infection among pregnant women attending antenatal clinic in Adeoyo Maternity Teaching Hospital Ibadan (AMTHI) Oyo state, Nigeria. Journal of Immunoassay \& Immunochemistry, 41(5):913-923.

Osundare, F. A., Klink, P., Majer, C., Akanbi, O. A., Wang, B., Faber, M., Harms, D., Bock, C. T., and Opaleye, O. O. (2020). Hepatitis E virus seroprevalence and associated risk factors in apparently healthy individuals from Osun state, Nigeria. Pathogens (Basel, Switzerland), 9(5): 392 . https://doi.org/10.3390/pathog ens 9050 392

Pavio, N., Meng, X. J., and Renou, C. (2010). Zoonotic hepatitis E: animal reservoirs and emerging risks. Veterinary Research, 41(6):46-60.

Pérez-Gracia, M. T., García, M., Suay, B. and Mateos-Lindemann, M. L. (2015). "Current knowledge on hepatitis E". Journal of Clinical and Translational Hepatology, 3(2): 117-126.

Skidmore S. (2002). Overview of hepatitis E virus. Current Infectious Disease Report, 4:118-123.

Thiry, D., Mauroy, A., Pavio, N., Purdy, M. A., Rose, N., Thiry, E., and de Oliveira-Filho, E. F. (2015). Hepatitis E virus and related viruses in animals. Transboundary Emerging Diseases, 64(1):37-52.

Tsega, E., Krawczynski, K., Hansson, B. G., and Nordenfelt, E. (1993). Hepatitis E virus infection in pregnancy in Ethiopia. 
Ethiopian Medical Journal, 31:173-181.

WHO (2010). World Health Organization.

The global prevalence of $\mathrm{HEV}$ infection and susceptibility. A systematic review. 